\title{
Induksi Mutasi Fisik dengan Iradiasi Sinar Gamma pada Kunyit (Curcuma domestica Val.)
}

\author{
Physical Mutation Induced by Gamma Ray Iradiation on Turmeric (Curcuma domestica Val.)
}

\author{
Syahidah Rosyidah Anshori ${ }^{1 *}$, Syarifah Iis Aisyah ${ }^{1}$ dan Latifah K Darusman ${ }^{2}$
}

Diterima 4 Maret 2014/Disetujui 21 Juli 2014

\begin{abstract}
Turmeric is a spice plant and potential as a major ingredient of functional food. Turmeric contains curcumin, an active compound which gives the yellow color from its rhizomes that provides health benefits. Curcumin is an antioxidant and acts as an anti-cholesterol as well as a medicine for tumors, cancer, hypertension, hyperglycemia, and rheumatic heart disease. Limited supply of simplicia level of curcumin based on market standards and the low genetic variability of turmeric as a source for conventional breeding makes this research valuable to be conducted. The purposes of this study were to obtain LD50 dose and turmeric crop yield variability due to the changes in physical mutation induced by gamma-ray irradiation. An acute single iradiation was given to using the universal panoramic irradiator with 11 different dose rates, The plants then were cultivated in vivo. The growth observation on turmeric was observed on vegetative traits qualitatively and quantitatively. In this study, the LD50 dose of turmeric was $47.26 \mathrm{~Gy}$. The plant's vegetative growth tends to decelerate with the increase of irradiation doses. The high variabillity growth for leaf number occured on 50 Gy of dose. Morphological changes occured in the form of pseudo-stem shape due to irradiation doses of 50 and 60 Gy. Most leaf surface discoloration and leaf deformation occured at 50 and $70 \mathrm{~Gy}$, and stunted growth occured at 60 and $70 \mathrm{~Gy}$.
\end{abstract}

Keywords: curcumin, iradiation, $L D_{50,}$ turmeric

\begin{abstract}
ABSTRAK
Kunyit merupakan tanaman rempah yang potensial sebagai bahan utama pangan fungsional. Rimpang kunyit mengandung senyawa aktif utama yaitu kurkumin yang memberikan warna kuning pada rimpang juga memberikan manfaat untuk kesehatan. Kurkumin bersifat antioksidan dan berperan sebagai antikolesterol, obat tumor, kanker, obat hipertensi, hiperglikemia, penyakit hati serta rematik. Keterbatasan penyediaan simplisia yang mempunyai kandungan kurkumin sesuai standar pasar serta rendahnya keragaman genetik kunyit sebagai bahan seleksi pemuliaan konvensional menjadikan penelitian ini penting untuk dilakukan. Tujuan penelitian ini adalah untuk mendapatkan dosis $\mathrm{LD}_{50}$ serta menghasilkan perubahan keragaan tanaman kunyit akibat induksi mutasi fisik melalui iradiasi sinar gamma. Iradiasi dilakukan secara tunggal (acute irradiation) menggunakan Iradiator Panorama Serba Guna (IRPASENA) dengan 11 taraf dosis yang berbeda dan tanaman yang telah diradiasi dibudidayakan secara in vivo. Pengamatan pertumbuhan tanaman kunyit dilakukan pada karakter vegetatif secara kuantitatif dan kualitatif. Pada penelitian ini, didapatkan $\mathrm{LD}_{50}$ kunyit yaitu pada dosis $47.26 \mathrm{~Gy}$. Pertumbuhan vegetatif tanaman cenderung mengalami perlambatan dengan semakin meningkatnya dosis iradiasi. Keragaman tertinggi pertumbuhan jumlah daun terdapat pada aplikasi dosis 50 Gy. Perubahan morfologi berupa bentuk pangkal batang semu terjadi pada tanaman akibat iradiasi dosis 50 dan $60 \mathrm{~Gy}$, perubahan warna sebagian permukaan daun dan terjadi pada 50 dan $70 \mathrm{~Gy}$, perubahan bentuk daun terjadi pada 50 dan $70 \mathrm{~Gy}$, serta pertumbuhan tanaman yang kerdil terjadi pada tanaman 60 dan $70 \mathrm{~Gy}$.
\end{abstract}

Kata kunci: iradiasi, kunyit, kurkumin, $\mathrm{LD}_{50}$

\footnotetext{
${ }^{1}$ Departemen Agronomi dan Hortikultura, Fakultas Pertanian, Institut Pertanian Bogor, Jl. Meranti Kampus IPB Darmaga, Bogor 16680, Indonesia, Telp.\&Faks.62-251-8629353 email agronipb@indo.net.id

${ }^{2}$ Pusat Studi Biofarmaka, Lembaga Penelitian dan Pengabdian kepada Masyarakat, Institut Pertanian Bogor, Jl. Taman Kencana No.03, Bogor 16128, Indonesia. Telp. 62-251-8373561 \& Faks. 62-251-8347525 email bfarmaka.lub@gmail.com

*Penulis untuk korespondensi: syahidahanshori@gmail.com
} 


\section{PENDAHULUAN}

Pangan fungsional merupakan pangan yang mempunyai fungsi fisiologis pada tubuh manusia dan berbahan utama tanaman obat dan rempah. Tanaman obat yang potensial dibudidayakan yaitu kunyit.

Senyawa aktif utama dalam rimpang kunyit yang mempunyai keaktifan fisiologi adalah kurkumin/kurkuminoid (Rahardjo dan Rostiana, 2005; Winarti dan Nurdjanah, 2005). Kurkuminoid adalah komponen yang memberikan warna kuning pada rimpang dan bersifat antioksidan serta berkhasiat sebagai antikolesterol, obat tumor, kanker dan antiinflamasi (Winarti dan Nurdjanah, 2005).

Kebutuhan masyarakat Indonesia terhadap kunyit sebesar 12000 ton tahun ${ }^{-1}$ untuk obat hipertensi dan untuk obat hiperglikemia sebanyak 1940 ton tahun ${ }^{-1}$ dimulai tahun 2010 (Pribadi, 2012). Tingkat kebutuhan pasar dari tahun ke tahun semakin meningkat dengan persentase $10-25 \%$ per tahunnya. Kebutuhan kunyit dunia hingga saat ini mencapai ratusan ribu ton per tahun (Satriani, 2010). Kementan (2013) menambahkan bahwa pengembangan tanaman kunyit termasuk dalam usaha program ketahanan pangan. Kebutuhan kunyit yang besar dipengaruhi oleh kandungan senyawa fitokimia di dalamnya, diantaranya yaitu kurkuminnya.

Penyediaan bahan baku kunyit dalam negeri masih menghadapi kendala yaitu keterbatasan penyediaan simplisia yang mempunyai kandungan kurkumin sesuai standar pasar (Wardiyati, 2009). Kendala dalam produksi kurkumin secara konvensional adalah rendahnya keragaman genetik sehingga populasi dasar untuk dijadikan bahan seleksi kandungan kurkumin sangat terbatas.

Saat ini, terdapat teknologi peningkatan keanekaragaman genetik tanaman yaitu mutasi (Odeigah et al., 1998). Van harten (2002 dalam Aisyah, 2013) menyatakan bahwa kombinasi mutasi dengan pembiakan vegetatif dapat menurunkan resiko kehilangan karakter mutan akibat segregasi. Penelitian Gatari dan Melati (2014) menunjukkan bahwa komposisi media tanam ternyata tidak mempengaruhi peubah vegetatif dan komponen hasil pada tanaman tempuyung. Selain itu, kerusakan yang disebabkan oleh mutasi dapat mengakibatkan perubahan biokimiawi sel, dalam hal ini proses biosintesis kurkumin pada kloroplas. Melalui metode mutasi induksi diharapkan secara tidak langsung mampu meningkatkan kadar kurkumin kunyit. Langkah awal, tujuan dari penelitian ini adalah menghasilkan perubahan keragaan dan menentukan dosis $\mathrm{LD}_{50}$ iradiasi sinar gamma pada tanaman kunyit.

\section{BAHAN DAN METODE}

Penelitian dilaksanakan di daerah Darmaga Bogor dengan ketinggian $270 \mathrm{~m}$ di atas permukaan laut $(\mathrm{m} \mathrm{dpl})$, suhu $26{ }^{\circ} \mathrm{C}$ bulan $^{-1}$, kelembaban udara $70 \%$, dan curah hujan 3500-4000 mm tahun ${ }^{-1}$ (Insani, 2013). Bahan tanam berasal dari kebun PT Soho di Cihanjawar Sukabumi, perusahaan yang berkordinasi dengan Pusat Studi Biofarmaka Lembaga Penelitian dan Pengabdian kepada Masyarakat Institut Pertanian Bogor (PSBLPPM IPB). Kegiatan iradiasi dilaksanakan di Pusat Aplikasi Teknologi Isotop dan Radiasi (PATIR), Badan Tenaga Nuklir Nasional (BATAN), Pasar Jum'at, Jakarta Selatan. Penelitian dilaksanakan pada bulan Juni hingga Desember 2013.

Bahan utama yang digunakan adalah rimpang kunyit aksesi Wonogiri. Bahan lainnya yaitu media tanah latosol, pupuk kandang sapi, pupuk kascing, dan arang sekam. Alat yang digunakan yaitu Iradiator Panorama Serba Guna (IRPASENA), mini RHCC (Royal Horticulture Colour Chart), box plastik, polybag, handsprayer, plastik, alat tulis, penggaris, label dan kamera digital.

Penelitian ini dilaksanakan menggunakan Rancangan Acak Lengkap (RAL) 1 faktor taraf dosis iradiasi. Taraf dosis yang digunakan meliputi $0,10,20,30,40,50,60$, 70, 80, 90, dan 100 Gy. Setiap taraf diperlakukan kepada rata-rata jumlah tunas pada rimpang yaitu 45-48 buah, dengan keragaman ukuran rimpang yang relatif sama tiap perlakuan. Pengukuran keragaman dilakukan melalui pengamatan visual.

Penelitian diawali dengan persiapan bahan iradiasi dan pembibitan selama 6 minggu. Penanaman di dalam polybag ukuran $35 \mathrm{~cm} \times 35 \mathrm{~cm}$ dengan media campuran tanah, pupuk kandang sapi dan arang sekam, 1:1:1/2 (v/v), dilakukan selama 17 minggu. Pemeliharaan meliputi penyiraman, pembumbunan 
dan penyiangan gulma. Pengamatan pertumbuhan tanaman kunyit dilakukan pada karakter vegetatif dengan indikator kuantitatif yaitu tinggi tanaman, panjang batang semu, jumlah anakan, jumlah daun, panjang daun, lebar daun, dan panjang tangkai daun. Indikator kualitatif tanaman yaitu warna daun dan batang. Hasil pengamatan diuji dengan analisis sidik regresi dan korelasi. Nilai $\mathrm{LD}_{50}$ diketahui menggunakan curve-fit analysis.

\section{HASIL DAN PEMBAHASAN}

\section{Kondisi Umum}

Kunyit dapat tumbuh dengan baik pada ketinggian 240-1200 m dpl dan curah hujan 2000-4000 mm tahun ${ }^{-1}$ (Rahardjo dan Rostiana, 2005). Berdasarkan pedoman syarat tumbuh tersebut, maka penanaman kunyit sesuai bila dilakukan di daerah Darmaga Bogor.

Syarat rimpang kunyit dapat dijadikan bibit yaitu hasil dari tanaman yang jelas jenis dan varietasnya, cukup umur (11-12 bulan) serta berkadar air cukup. Pada penelitian ini, digunakan kunyit aksesi Wonogiri yang mempunyai kadar kurkumin tertinggi yaitu $3.99 \%$ (Kautsar, 2012) dan ada juga yang menyatakan $9.55 \%$ (Syifa, 2012). Pada penelitian ini, kunyit yang digunakan berasal dari tanaman berumur 4 bulan. Hal tersebut mengakibatkan pertumbuhan tunas yang lambat hingga 14 MSI (minggu setelah iradiasi). Aisyah (2013) menjelaskan bahwa jika iradiasi diberikan kepada jaringan yang mengandung banyak air maka radikal-radikal bebas dari iradiasi akan merusak sel dengan cepat.

Selama masa penanaman, terdapat sedikit penyakit busuk rimpang disebabkan oleh bakteri Ralstonia solanacearum pada tanaman perlakuan 50, 80, 90, dan $100 \mathrm{~Gy}$ yang kemungkinan disebabkan oleh bakteri. Bakteri dapat muncul akibat drainase yang kurang baik. (Rahardjo dan Rostiana, 2005).

Penelitian yang dilakukan oleh Solanki dan Sharma (2000 dalam Wulan, 2007) menggunakan iradiasi tunggal untuk memunculkan mutan dan bahan tanamnya menggunakan benih. Pada penelitian ini, teknik iradiasi yang diterapkan adalah teknik iradiasi Acute (iradiasi tunggal). Bahan tanam yang digunakan berupa rimpang muda yang mengandung banyak air (oksigen). Pengaruh dari perlakuan perbedaan taraf dosis iradiasi mengakibatkan perbedaan pada waktu tumbuhnya tunas rimpang kunyit.
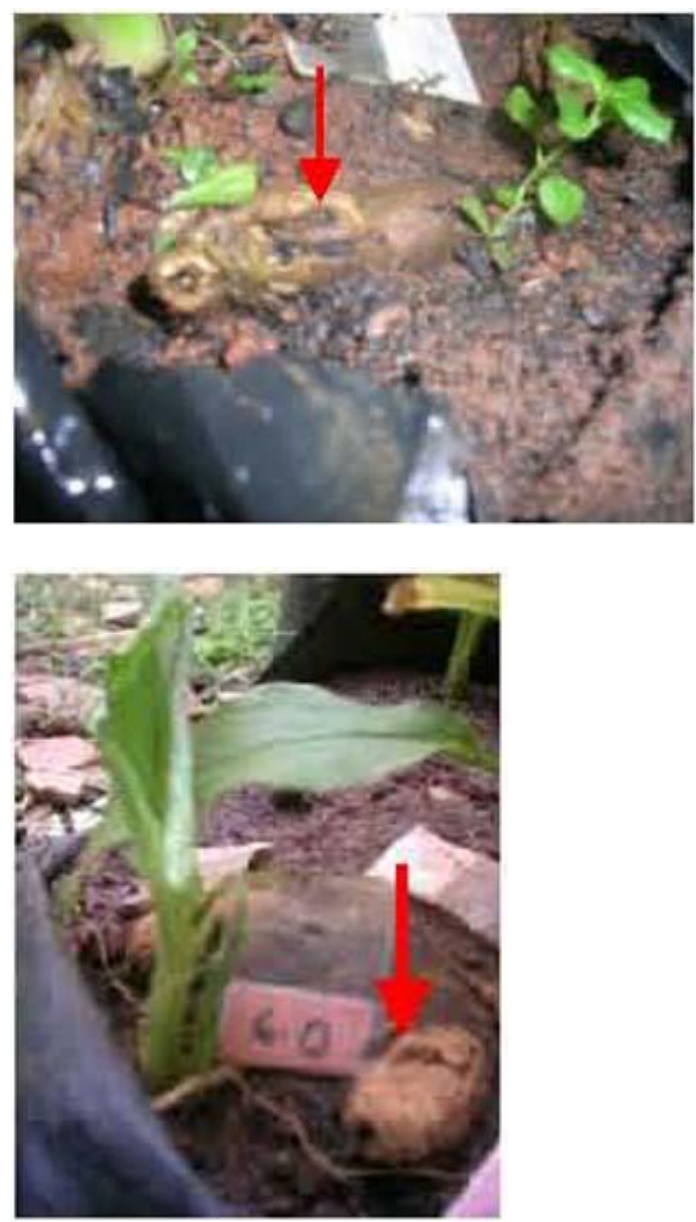

Gambar 1. Penyakit busuk rimpang

\section{Lethal Dose 50}

Perlakuan taraf dosis iradiasi menyebabkan perbedaan persentase tanaman tumbuh yang nyata. Ditunjukkan pada Tabel 1, dosis 80, 90, dan 100 Gy mengakibatkan tanaman mati. Hal itu sesuai dengan penelitian yang dilakukan oleh Pramono (2011), yang menggunakan sinar gamma dan diaplikasikan pada tanaman iles-iles menghasilkan kematian tanaman. Perubahan fenotipe yang dihasilkan akibat mutasi bervariasi, mulai dari perubahan minor yang hanya terdeteksi dengan metode analisis biokimia sampai perubahan drastis yang terjadi di dalam proses metabolisme yang esensial sehingga menimbulkan kematian sel atau organisme. 
Tabel 1. Persentase tanaman hidup pada umur tanaman 23 MSI

\begin{tabular}{rccc}
\hline $\begin{array}{l}\text { Dosis } \\
\text { (Gy) }\end{array}$ & $\begin{array}{c}\text { Tanaman } \\
\text { hidup }(\%)\end{array}$ & $\begin{array}{c}\text { Dosis } \\
(\mathrm{Gy})\end{array}$ & $\begin{array}{c}\text { Tanaman } \\
\text { hidup }(\%)\end{array}$ \\
\hline 0 & 77.78 & 60 & 11.11 \\
10 & 55.56 & 70 & 66.67 \\
20 & 44.44 & 80 & 0.00 \\
30 & 55.56 & 90 & 0.00 \\
40 & 88.89 & 100 & 0.00 \\
50 & 66.67 & & \\
\hline
\end{tabular}

Aisyah (2006) mengungkapkan bahwa umumnya mutasi yang diinginkan akan terletak pada kisaran dosis $\mathrm{LD}_{50}$. Angka $\mathrm{LD}_{50}$ didapatkan dengan menggunakan software curve fit analysis. Program tersebut merekomendasikan kurva Modified Power (Gambar 2) yang mempunyai persamaan $\mathrm{y}=$ $25.717947 * 1.0141655^{\mathrm{x}}$ dengan nilai S (standar deviasi) terendah dan nilai $r$ (koefisien korelasi) tertinggi. Berdasarkan program tersebut, $\mathrm{LD}_{50}$ dosis iradiasi sinar gamma pada tanaman kunyit yaitu sebesar 47.26 Gy.

Pada percobaan ini, nilai data terendah terdapat pada perlakuan 40 Gy. Hal ini menunjukkan bahwa penggunaan dosis di bawah atau di atas $40 \mathrm{~Gy}$ akan menyebabkan tingginya jumlah tanaman yang mati. Hal tersebut dapat dipengaruhi oleh tingkat radiosensitivitas rimpang kunyit yang tinggi terhadap dosis iradiasi pada rentang $\mathrm{LD}_{50}$, dimana dapat menyebabkan kerusakan fisiologi maupun genetik.

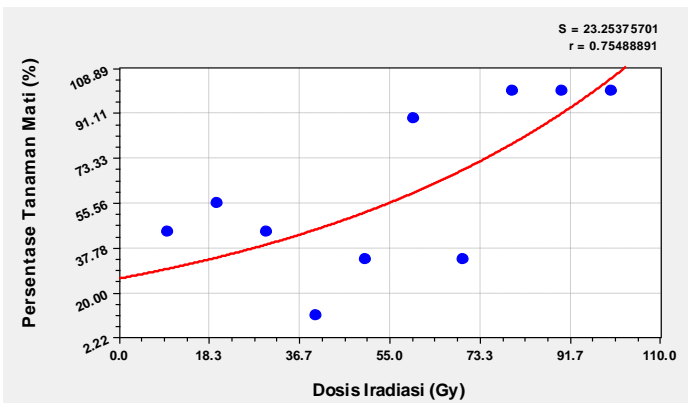

Gambar 2. Persentase tanaman mati berdasarkan software curve fit analysis

\section{Karakter Kuantitatif}

Tanaman dari setiap perlakuan, tumbuh pada waktu yang berbeda (tidak serentak), bahkan ada yang menunjukkan kematian. Hal tersebut tampak pada Gambar 3.

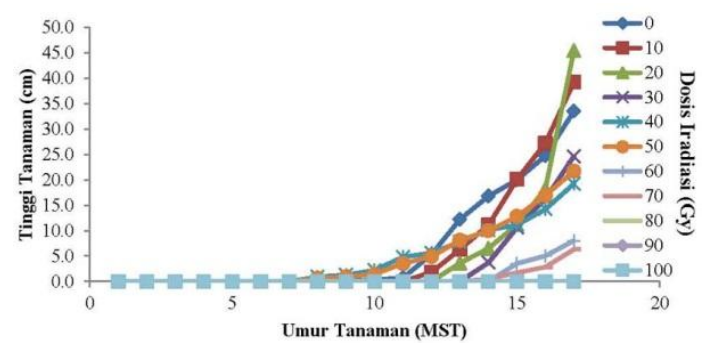

Gambar 3. Perbandingan waktu tumbuh dan tinggi tanaman akibat taraf dosis iradiasi

Tanaman akibat iradiasi tumbuh pada waktu yang berbeda. Dosis 0, 10, 20, 30 dan 70 Gy, 40 dan 50 Gy, serta 60 Gy berturutturut tumbuh pada waktu yang berbeda yaitu umur tanaman 10, 12, 13, 14, 8, dan 15 MST. Adapun tanaman dosis 80, 90, dan 100 Gy tidak mengalami pertumbuhan. Hal tersebut menunjukkan bahwa semakin tinggi perlakuan dosis iradiasi pada kunyit, maka pertumbuhan bibitnya akan semakin lambat, walaupun hal itu tidak berlaku pada 40 dan 50 Gy yang memberikan karakter yang positif dibanding dengan kontrol. Iradiasi sinar gamma yang menyebabkan terjadinya mutasi secara acak mengakibatkan kerusakan fisiologis dalam metabolisme perkembangan sel, sehingga potensi pertumbuhannya dapat lebih cepat atau lebih lambat.

\section{Korelasi Dosis dengan Pertumbuhan Vegetatif}

Aplikasi dosis iradiasi yang semakin meningkat memberikan pengaruh pertumbuhan pada berbagai karakter vegetatif yang cenderung semakin menurun, dengan pola hubungan yang berbeda pada setiap karakter (Gambar 4). Tingkat dosis iradiasi berkorelasi dengan lamanya pemaparan sinar gamma terhadap materi. Penelitian yang dilakukan oleh Indrayanti et al. (2012) berupa iradiasi sinar gamma pada bibit pisang menunjukkan peningkatan dosis iradiasi berhubungan dengan tinggi tanaman, panjang daun, serta rasio panjang dan lebar daun. Rashid et al. (2013) juga melaporkan berupa iradiasi sinar gamma pada jahe menghasilkan penurunan tingkat rata-rata pertumbuhan tunas dan tanaman dengan semakin meningkatnya lama pemaparan sinar gamma.

Tinggi tanaman, panjang batang semu, panjang daun ke-3 dan lebar daun ke-3 
ditunjukkan dalam bentuk kurva polinomial derajat ke-4. Nilai koefisien korelasi (r) sebesar $0.85 \quad(\mathrm{r} \approx 1)$ pada karakter tinggi tanaman menunjukkan adanya keeratan hubungan antara peningkatan dosis iradiasi dengan pertumbuhan tinggi tanaman. Setiap kenaikan dosis iradiasi menghasilkan perubahan pertumbuhan tinggi tanaman secara serempak dengan rentang yang hampir sama. Menurut Aisyah (2013), tinggi tanaman yang semakin menurun akibat perlakuan merupakan indikator yang paling umum untuk melihat efek dari mutagen. Peningkatan dosis iradiasi mempunyai keeratan hubungan dengan pertumbuhan panjang batang semu dengan nilai $r$ sebesar 0.924 , $(r \approx 1)$, begitu juga pada hubungannya dengan panjang dan lebar daun ke-3 yang memiliki nilai korelasi berturutturut 0.97 dan 0.96 .
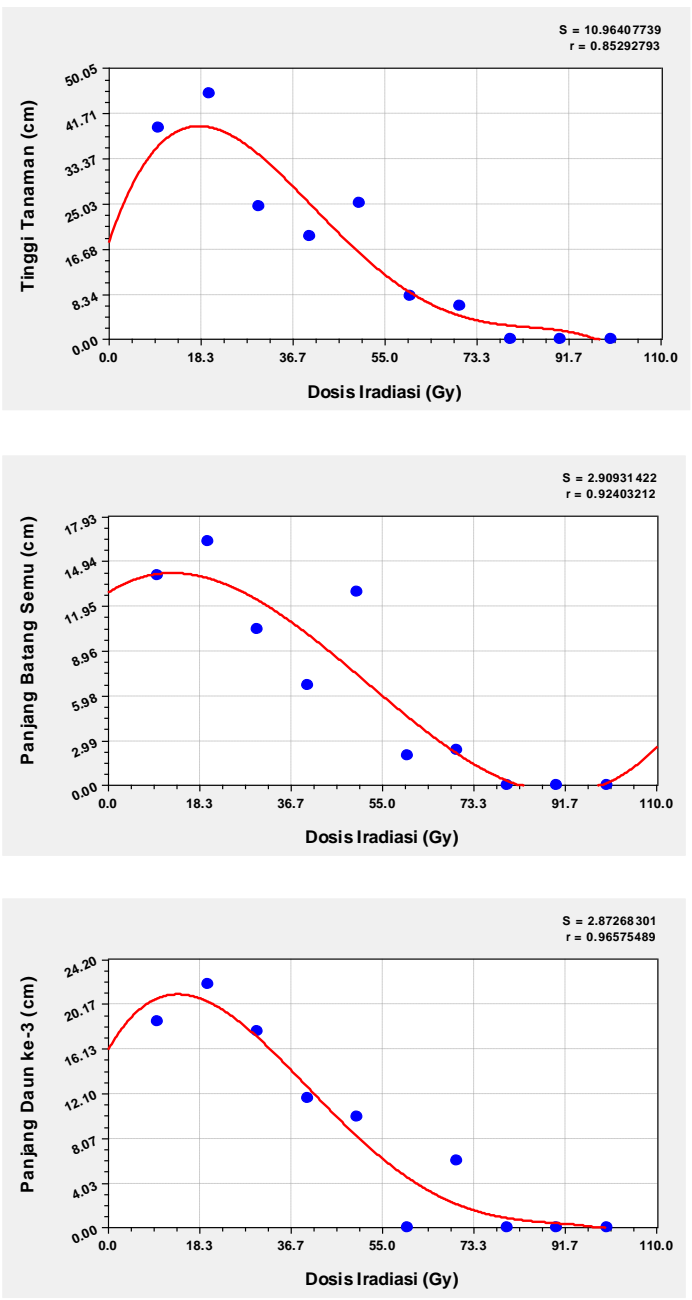
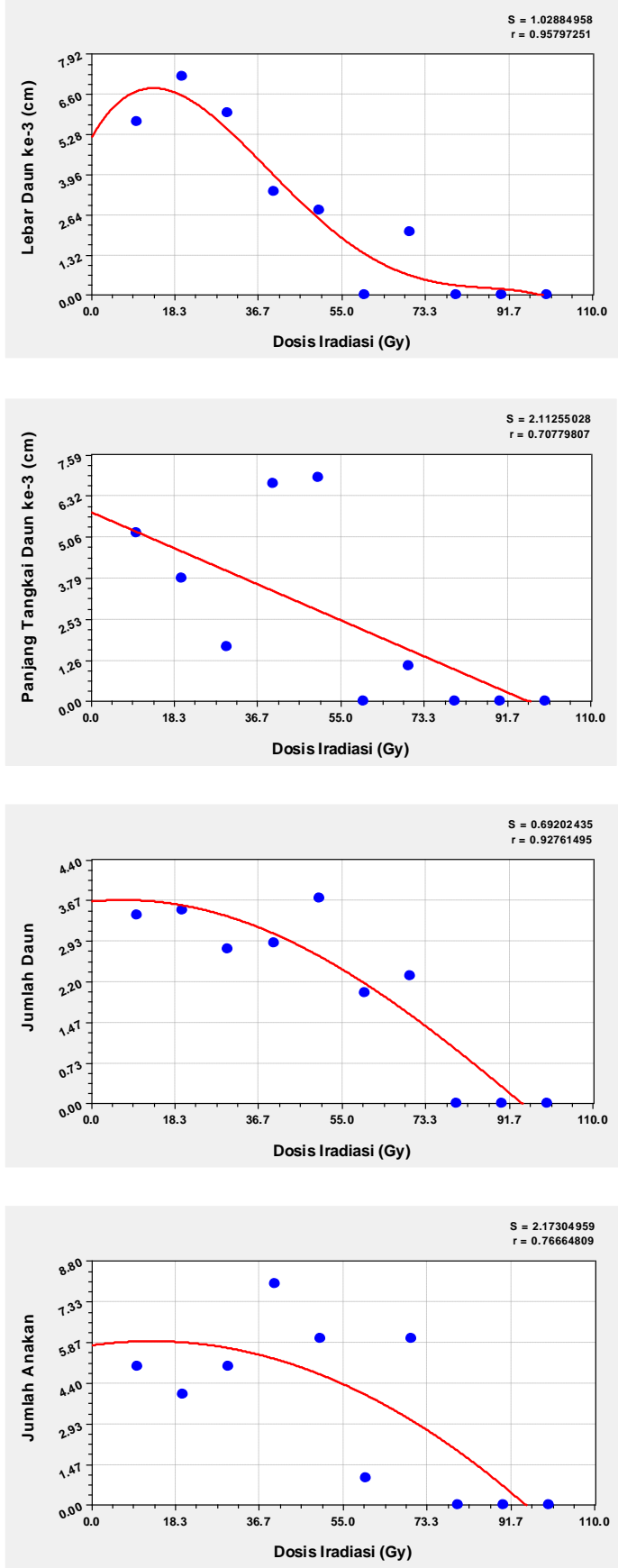

Gambar 4. Pertumbuhan vegetatif tanaman pada 17 MST

Panjang tangkai daun ke-3 mengikuti fungsi korelasi linear negatif terhadap peningkatan dosis iradiasi dengan tingkat keeratan hubungan sebesar 0.71 . Hal tersebut dapat diartikan bahwa perlakuan dosis radiasi berpengaruh nyata pada pertumbuhan panjang tangkai daun ke-3. Korelasi yang negatif menunjukkan bahwa semakin meningkat taraf 
dosis iradiasi maka pertumbuhan karakter pertumuhan tersebut semakin menurun. Sebesar $49 \%$ keragaman panjang tangkai daun ke-3 dapat diterangkan oleh fungsi linear dosis iradiasi.

Pertambahan jumlah daun dan anakan akibat perlakuan membentuk fungsi kuadratik, dengan keeratan masing-masing karakter adalah 0.92 (sangat tinggi) dan 0.77 (cukup tinggi). Pada percobaan ini, pola kuadratik menunjukkan adanya dosis yang memberikan pertumbuhan jumlah daun dan anakan paling optimal pada tanaman Mutan vegetatif generasi 1 (MV1) yaitu pada 1.5 dan 12.83 Gy. Mutan vegetatif generasi 1 atau MV1 adalah populasi tanaman hasil perbanyakan vegetatif dari bahan tanam yang telah diradiasi.

\section{Keragaman Pertumbuhan Vegetatif Tanaman}

Keragaman pertumbuhan karakter vegetatif tanaman dapat diketahui melalui nilai ragamnya yang dinyatakan dalam standar deviasi (SD), seperti yang tercantum pada Tabel 2. Semakin tinggi SD maka semakin tinggi tingkat keragaman. Diketahui bahwa hanya dosis iradiasi 50 Gy yang memberikan keragaman tertinggi yaitu pada jumlah daun. Hal tersebut sesuai dengan penelitian yang dilakukan oleh Wardhani (2005) bahwa induksi mutasi fisik menggunakan iradiasi sinar gamma pada anggrek dapat mempengaruhi nilai jumlah daun. Adanya dosis iradiasi yang mengakibatkan keragaman tertinggi menjadi rekomendasi bagi pemulia tanaman sesuai kebutuhan.

Tabel 2. Pertumbuhan rata-rata vegetatif tanaman perlakuan pada 17 MST

\begin{tabular}{ccrrrrc}
\hline Dosis (Gy) & \multicolumn{1}{c}{ TT } & PBS & PD3 & LD3 & PTD3 & JD \\
\hline 0 & $33.5 \pm 21.9$ & $12,5 \pm 7.9$ & $16.7 \pm 5.6$ & $5.3 \pm 2.0$ & $5.3 \pm 3.6$ & $4.0 \pm 1.4$ \\
10 & $39.2 \pm 3.6$ & $14.0 \pm 2.5$ & $18.6 \pm 3.9$ & $5.7 \pm 1.5$ & $5.2 \pm 1.3$ & $3.4 \pm 1.7$ \\
20 & $45.4 \pm 12.3$ & $16.3 \pm 3.8$ & $22.0 \pm 3.8$ & $7.2 \pm 1.8$ & $3.8 \pm 1.0$ & $3.5 \pm 1.0$ \\
30 & $24.6 \pm 11.2$ & $10.4 \pm 4.8$ & $17.7 \pm 2.1$ & $6.0 \pm 0.4$ & $1.7 \pm 0.8$ & $2.8 \pm 0.5$ \\
40 & $19.2 \pm 14.6$ & $6.7 \pm 6.7$ & $11.7 \pm 1.1$ & $3.4 \pm 0.2$ & $6.7 \pm 3.3$ & $2.9 \pm 0.1$ \\
50 & $21.7 \pm 15.2$ & $12.9 \pm 4.4$ & $10.0 \pm 4.1$ & $2.8 \pm 0.9$ & $6.9 \pm 2.5$ & $3.7 \pm 2.7$ \\
60 & $8.0 \pm 0.0$ & $2.0 \pm 0.0$ & $0.0 \pm 0.0$ & $0.0 \pm 0.0$ & $0.0 \pm 0.0$ & $2.0 \pm 0.0$ \\
70 & $6.3 \pm 3.4$ & $2.4 \pm 0.2$ & $6.1 \pm 0.1$ & $2.1 \pm 0.1$ & $1.1 \pm 0.3$ & $2.3 \pm 0.9$ \\
80 & $0.0 \pm 0.0$ & $0.0 \pm 0.0$ & $0.0 \pm 0.0$ & $0.0 \pm 0.0$ & $0.0 \pm 0.0$ & $0.0 \pm 0.0$ \\
90 & $0.0 \pm 0.0$ & $0.0 \pm 0.0$ & $0.0 \pm 0.0$ & $0.0 \pm 0.0$ & $0.0 \pm 0.0$ & $0.0 \pm 0.0$ \\
100 & $0.0 \pm 0.0$ & $0.0 \pm 0.0$ & $0.0 \pm 0.0$ & $0.0 \pm 0.0$ & $0.0 \pm 0.0$ & $0.0 \pm 0.0$
\end{tabular}

Keterangan: TT= tinggi tanaman $(\mathrm{cm}) ; \mathrm{PBS}=$ panjang batang semu $(\mathrm{cm}) ; \mathrm{PD} 3=$ panjang daun ke-3 $(\mathrm{cm}) ; \mathrm{LD} 3=$ lebar daun ke-3 $(\mathrm{cm})$; PTD3= panjang tangkai daun ke-3 $(\mathrm{cm})$; JD= jumlah daun

\section{Karakter Kualitatif}

Pengamatan warna yang dilakukan terhadap daun ke-3 pada umur tanaman 17 MST memberikan keragaan yang serupa antar perlakuan yaitu warna hijau gelap (dark green), kecuali pada perlakuan dosis iradiasi 20 dan 30 Gy yaitu berwarna hijau kekuningan (yellow green), seperti yang tampak pada Tabel 3.

Pada perkembangan selanjutnya, warna daun pada dosis-dosis tersebut menjadi hijau gelap. Perlakuan dosis iradiasi tidak memberikan perubahan warna pada daun. Begitu pula pada batang semu yang seluruhnya berwarna hijau kekuningan.
Tabel 3. Klasifikasi warna daun tanaman

\begin{tabular}{cccc}
\hline $\begin{array}{c}\text { Dosis } \\
(\mathrm{Gy})\end{array}$ & Warna & $\begin{array}{c}\text { Dosis } \\
(\mathrm{Gy})\end{array}$ & Warna \\
\hline 0 & RHS 144A & 60 & - \\
10 & RHS 144A & 70 & $\begin{array}{c}\text { RHS } \\
\end{array}$ \\
20 & RHS 145A* & 80 & - \\
30 & RHS 145A* & 90 & - \\
40 & RHS 144A & 100 & - \\
50 & RHS 144A & & \\
\hline
\end{tabular}

Keterangan: * perubahan warna hanya terjadi pada 1 lembar daun 1 tanaman perlakuan. RHS $145 \mathrm{~A}=$ yellow green, RHS $144 \mathrm{~A}=$ dark green 


\section{Perubahan Morfologi Tanaman}

Boertjes dan Van Harten (1988) mengemukakan bahwa ada dua macam pengaruh yang dapat terjadi setelah iradiasi yaitu kerusakan fisiologis dan kerusakan genetik (mutasi). Kerusakan genetik pada tanaman Mutan vegetatif generasi 1 (MV1) dapat secara sederhana dilihat melalui perubahan morfologinya, sehingga tanaman tersebut dikenal sebagai putative mutan. Putative mutan adalah tanaman yang dianggap sebagai mutan. Pada generasi berikutnya, diharapkan perubahan tersebut dapat dibuktikan terjadi secara genetik. Pada penelitian ini, terjadi kemungkinan kerusakan genetik tanaman (umur 20 MST) pada bentuk pangkal batang semu, seperti yang ditunjukkan oleh Gambar 5(a).

Perubahan bentuk pangkal batang semu terjadi pada tanaman perlakuan 50 dan $60 \mathrm{~Gy}$. Pada tanaman normal (0 Gy), satu anakan tanaman ditunjukkan dengan hanya satu batang semu dan filotaksis daun seperti pada Gambar 5(b). Pada perlakuan 50 Gy, dua batang semu tanaman muncul dari satu anakan. Adapun yang ditunjukkan pada perlakuan $60 \mathrm{~Gy}$, sebanyak 7 daun muncul secara bersamaan dari pangkal batang semu dengan arah pertumbuhan tidak mengikuti filotaksis kunyit. Diameter tangkai daun pun tidak berukuran seragam. Hal tersebut terjadi pula pada penelitian yang dilaksanakan oleh Rashid et al. (2013) dimana iradiasi sinar gamma pada jahe mampu mengakibatkan pertumbuhan tangkai daun yang bengkok. Keunikan yang terjadi pada tanaman perlakuan 50 dan 60 Gy menunjukkan bahwa iradiasi sinar gamma menyebabkan mutasi secara acak.

Penelitian yang dilakukan oleh Royani (2012), induksi mutasi fisik dengan iradiasi sinar gamma memberikan pengaruh perubahan karakter morfologi tanaman sambiloto terutama pada daun. Grosch dan Hapwood (1979) menambahkan bahwa iradiasi pada tanaman dapat meyebabkan bentuk daun yang berbeda-beda diantaranya penghambatan pertumbuhan (kerdil), penyatuan daun, dan mosaik (perubahan warna). Tanaman hasil penelitian ini menunjukkan adanya perubahan warna pada sebagian permukaan daun tanaman perlakuan dosis 50 dan 70 Gy (Gambar 6). Pada Gambar 7, perlakuan 50 dan 70 Gy menyebabkan perubahan bentuk sebagian lembar daun.
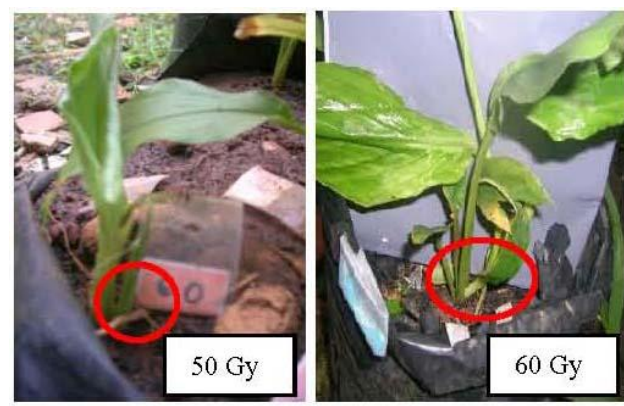

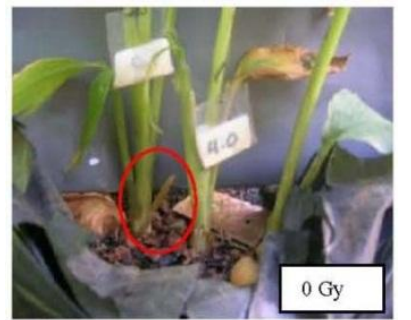

(a)

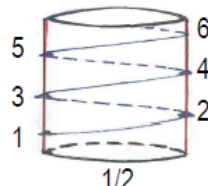

(b)
Gambar 5. (a) Perubahan bentuk pangkal batang semu; (b) filotaksis daun

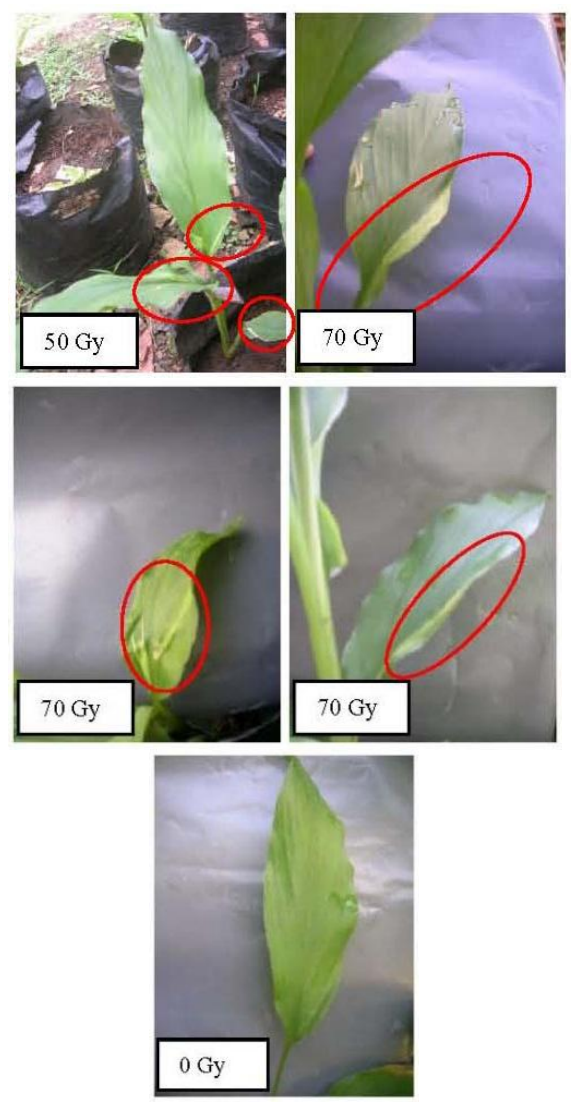

Gambar 6. Perubahan warna sebagian permukaan daun 


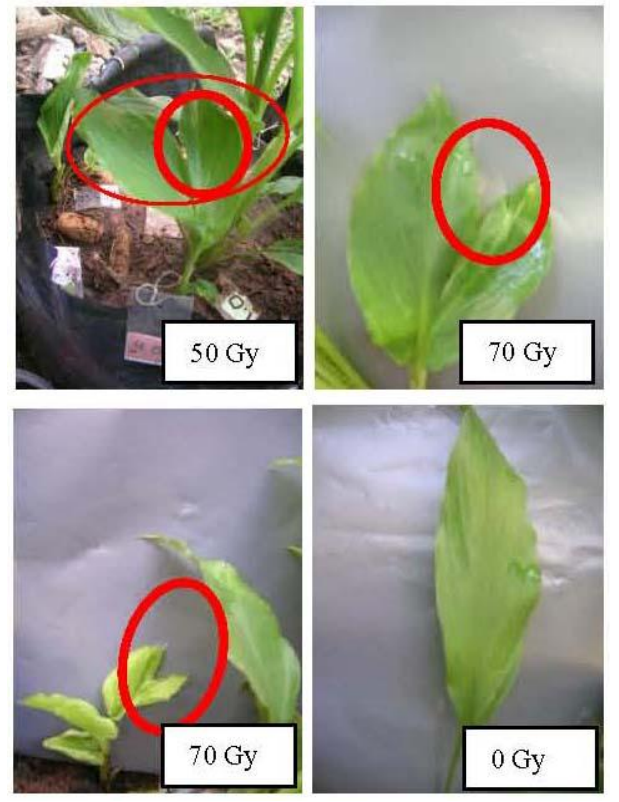

Gambar 7. Perubahan bentuk ujung daun

Semburat perubahan warna terjadi pada 3 lembar daun satu tanaman perlakuan 50 Gy dengan panjang sekitar 2-5 $\mathrm{cm}$ dan 3 lembar daun dari tanaman yang berbeda perlakuan 70 Gy dengan panjang kurang lebih $7 \mathrm{~cm}$. Perbandingan warna yang mencolok dengan daun tanaman kontrol (hijau gelap) yaitu hijau kekuningan. Perubahan yang terjadi pada sebagian karakter suatu jaringan tanaman (dalam hal ini warna) maka tanaman tersebut dinamakan kimera. Perubahan tersebut berupa jaringan tanaman yang memiliki dua atau lebih komponen genetik. Pada penelitian ini, tampak kimera terekspresi dari mutasi pada DNA kloroplas (cp DNA) yang mengakibatkan plastida pada sebagian jaringan kurang atau tidak bisa memproduksi klorofil, sedangkan sebagian yang lain produksi klorofil normal, sehingga daun sebagian berwarna hijau dan putih atau kuning. Perubahan karakter kloroplas dapat mempengaruhi biosintesis kurkumin. Heldt (1997) menyatakan bahwa daun dapat menyerap nitrogen dalam bentuk nitrat, kemudian kloroplas mengubahnya dalam bentuk amonium dan selanjutnya menjadi asam amino fenilalanin melalui jalur sikimat. Markham (1998) menambahkan bahwa asam amino tersebut merupakan asam amino prekusor untuk lintasan fenilpropanoid dalam biosintesis flavonoid. Kurkumin merupakan salah satu jenis metabolit sekunder flavonoid. Penelitian yang dilakukan oleh Ling et al. (2008) berupa iradiasi sinar gamma pada planlet Citrus sinensis menghasilkan peningkatan kandungan protein, namun kandungan klorofil yang dihasilkan tidak lebih tinggi jika dibandingkan dengan planlet tanpa iradiasi.

Bentuk daun tanaman kunyit secara normal adalah lanset yang memiliki satu ujung lancip. Pada Gambar 7 ditunjukkan bahwa perubahan yang terjadi pada sebagian daun tanaman akibat perlakuan baik iradiasi 50 maupun 70 Gy yaitu memiliki dua ujung lancip. Fenomena tersebut dapat disebut sebagai kimera. Van Harten (1998) mengungkapkan bahwa iradiasi pada bagian meristematik beresiko memunculkan kimera.

Dixit et al. (2002) dan Srivastava et al. (2006) mengungkapkan bahwa perubahan pada bentuk dan ukuran (luas permukaan) daun merupakan indikasi adanya perubahan pada kandungan $\mathrm{Zn}$ dan $\mathrm{B}$ yang berkorelasi secara positif. Perubahan kandungan Zn dan B dapat diketahui pula melalui perubahan pada parameter kualitatif dan kuantitatif pertumbuhan daun berupa berat basah dan kering, kandungan klorofil, tingkat perubahan $\mathrm{CO}_{2}$, tingkat transpirasi dan konduktans daun yang terutama terjadi pada semua lembar daun muda. Defisiensi Zn dan B secara signifikan dapat menurunkan kapasitas asimilasi $\mathrm{C}$ (karbon) daun, dan distribusinya menjadi gula, asam amino dan asam organik pada akar dan rizome. Kapasitas biosintesis dalam menghasilkan metabolit berupa minyak atsiri dan kurkumin pun akan menurun.

Iradiasi sinar gamma mampu mengakibatkan perubahan pada karakter tinggi tanaman. Seperti yang tampak pada Gambar 8, perubahan tinggi terjadi pada tanaman perlakuan 60 dan 70 Gy jika dibandingkan dengan tanaman tanpa radiasi (kontrol). Keragaan tanaman pada aplikasi dosis tersebut menunjukkan pertumbuhan yang kerdil. Fenomena tersebut termasuk ke dalam kerusakan fisiologis. Kerusakan fisiologis dapat diketahui melalui kematian sel (tanaman), pertumbuhan rata-rata dan perlambatan pertumbuhan.

Pertumbuhan tanaman yang kerdil didukung oleh nilai korelasi antara dosis dengan panjang batang semu dan jumlah daun pada dosis 60 dan 70 Gy tidak mendekati satu. Hal tersebut tampak pada Tabel 4 dan Gambar 9. Pertumbuhan tinggi tanaman yang maksimal dengan panjang batang semu dan jumlah daun yang optimal akan sulit ditemui pada tanaman 
perlakuan dosis tersebut. Pertumbuhan tanaman yang kerdil juga ditemukan pada hasil penelitian Rashid et al. (2013) dalam penggunaan iradiasi sinar gamma terhadap jahe. Pertumbuhan tanaman yang kerdil akan dapat menurunkan total luas permukaan daun.
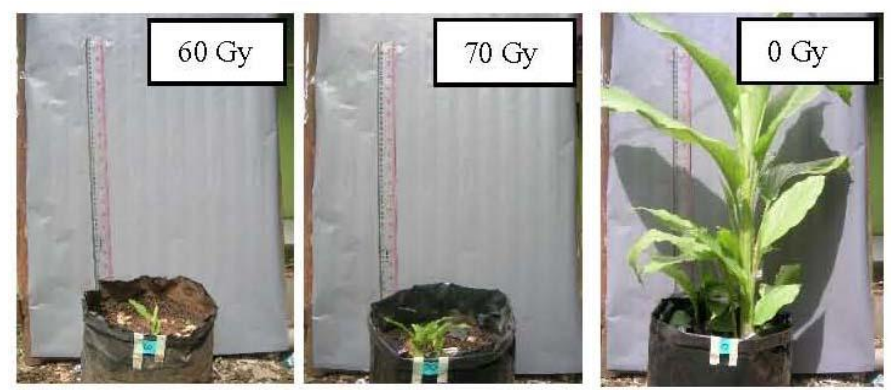

Gambar 8. Pertumbuhan tanaman kerdil

Tabel 4. Nilai koefisien korelasi antara 2 peubah pada 17 MST

\begin{tabular}{cccccccc}
\hline \multicolumn{2}{c}{ PBS x TT } & \multicolumn{2}{c}{ JD x TT } & \multicolumn{2}{c}{ PBS x TT } & \multicolumn{2}{c}{ JD x TT } \\
\hline Dosis (Gy) & $\mathrm{R}$ & Dosis (Gy) & $\mathrm{r}$ & Dosis (Gy) & $\mathrm{R}$ & Dosis (Gy) & $\mathrm{r}$ \\
\hline 0 & 0.999 & 0 & 0.999 & 60 & $0.785^{*}$ & 60 & $0.784^{*}$ \\
10 & 0.987 & 10 & 0.995 & 70 & $0.884^{*}$ & 70 & $0.927^{*}$ \\
20 & 0.993 & 20 & 0.989 & 80 & 1 & 80 & 1 \\
30 & 0.986 & 30 & 0.968 & 90 & 1 & 90 & 1 \\
40 & 0.989 & 40 & 0.986 & 100 & 1 & 100 & 1 \\
50 & 0.991 & 50 & 0.983 & & & & \\
\hline
\end{tabular}

Keterangan: *r tidak mendekati $1 . \mathrm{PBS}=$ panjang batang semu; TT= tinggi tanaman; JD= jumlah daun

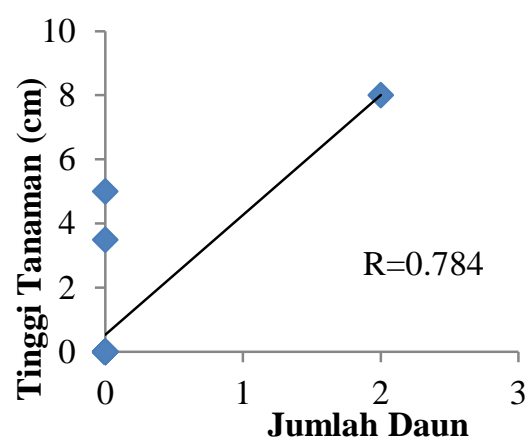

(a)

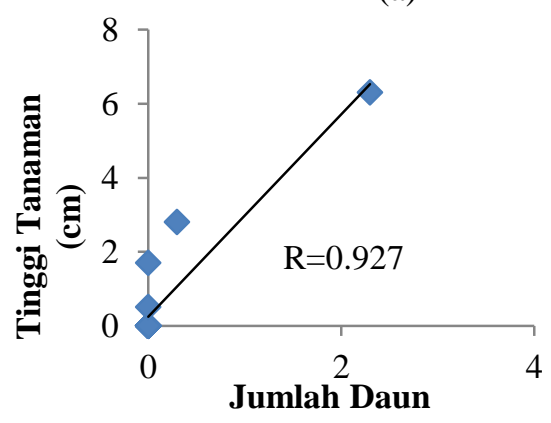

(b)

Gambar 9. Korelasi antara peubah tinggi tanaman dan jumlah daun pada perlakuan (a) 60 Gy dan (b) 70 Gy pada 17 MST
Secara umum, perubahan pada struktur genetik akan menyebabkan perubahan pada ekspresinya (bentuk protein). Perubahan tersebut berlanjut menyebabkan perubahan pada metabolisme. Kerusakan fisiologis juga mampu merubah metabolisme tanpa ada perubahan pada bahan genetiknya. Perubahan metabolisme akan menyebabkan perubahan pada kandungan kimia (protein, enzim, metabolit), perubahan morfologi (bentuk dan warna), perubahan daya adaptasi (akibat perubahan morfologi dan metabolisme), dan mutan kondisional.

\section{KESIMPULAN}

Induksi mutasi fisik dengan iradiasi sinar gamma mengakibatkan pertumbuhan bibit kunyit mengalami perlambatan hingga 14 minggu setelah iradiasi. Hubungan antara peningkatan dosis iradiasi dan penurunan pertumbuhan tanaman pada tiap karakter vegetatif dinyatakan sangat erat, kecuali pada karakter panjang tangkai daun ke-3 yang berhubungan cukup erat. Perlakuan 40 dan 50 Gy mengakibatkan karakter tanaman yang 
lebih positif dibanding tanaman kontrol dengan waktu pertumbuhannya yang lebih cepat. Keragaman tertinggi pertumbuhan jumlah daun terdapat pada perlakuan akibat iradiasi sinar gamma 50 Gy. Pada penelitian ini, didapatkan $\mathrm{LD}_{50}$ kunyit yaitu pada dosis 47.26 Gy.

Perlakuan iradiasi sinar gamma memberikan perubahan pada karakter morfologi tanaman. Perubahan terjadi pada bentuk pangkal batang semu salah satu anakan tanaman perlakuan iradiasi 50 dan $60 \mathrm{~Gy}$. Perubahan terjadi pula pada warna sebagian permukaan daun (semburat) tanaman perlakuan iradiasi 50 Gy dan 70 Gy. Terdapat perubahan bentuk pada beberapa lembar daun tanaman perlakuan iradiasi 50 dan 70 Gy. Tanaman akibat iradiasi 60 dan 70 Gy menghasilkan tanaman yang kerdil dibanding dengan tanaman tanpa iradiasi.

\section{SARAN}

Bahan tanam penelitian disarankan berasal dari rimpang kunyit yang telah cukup umurnya (11-12 bulan). Beberapa penelitian lanjutan perlu untuk dilakukan. Penelitian lanjutan dilaksanakan dengan menggunakan taraf dosis iradasi yang terdapat dalam rentang $\mathrm{LD}_{50}$ agar menghasilkan nilai $\mathrm{LD}_{50}$ yang lebih akurat dan keragaman yang lebih tinggi. Untuk meningkatkan efek iradiasi pada suatu jaringan dapat juga dihasilkan dari penelitian lanjutan berupa iradiasi berulang, baik recurrent maupun intermitent iradiation. Penelitian lanjutan lainnya dapat berupa penanaman kembali tanaman hasil iradiasi (MV1) agar bisa dilakukan seleksi pada populasi generasi selanjutnya (MV2, MV3 dan selanjutnya). Hal tersebut dilakukan hingga dapat membuktikan bahwa perubahan yang terjadi pada jaringan tanaman merupakan akibat dari perubahan genetik. Untuk mengetahui efek sitologis dari pengaruh mutagen terhadap tanaman dapat diamati di bawah mikroskop, guna menentukan tingkat efektifitas mutagen. Penelitian disarankan untuk dilakukan sampai panen sehingga dapat diketahui pengaruhnya terhadap kadar kurkumin rimpang kunyit.

\section{UCAPAN TERIMAKASIH}

Ucapan terimakasih penulis sampaikan kepada Pusat Studi Biofarmaka LPPM IPB atas kesempatan proyek serta bantuan dana yang diberikan guna mendukung pelaksanaan penelitian.

\section{DAFTAR PUSTAKA}

Aisyah, S.I. 2006. Induksi Mutagen Fisik pada anyelir (Dianthus caryophyllus Linn.) dan pengujian stabilitas mutannya yang diperbanyak secara vegetatif [disertasi]. Institut Pertanian Bogor. Bogor.

Aisyah, S.I. 2013. Mutasi induksi. p.197-210 in M. Syukur, S. Sastrosumarjo (Eds). Sitogenetika Tanaman. IPB Pr.

Boertjes, C., A.M.V. Harten. 1988. Applied Mutation Breeding for Vegetatively Propagated Crops. Elsevier. Amsterdam.

Dixit, D., N.K. Srivastava, S. Sharma. 2002. Boron deficiency induced changes in translocation of ${ }^{14} \mathrm{CO}_{2}$-photosynthate into primary metabolites in relation to essential oil dan curcumin. Photosynthetica J. 40(1): 109-113.

Gatari, D.D., M. Melati. 2014. Pertumbuhan dan produksi tanaman tempuyung (Sonchus arvensis L.) dengan komposisi media tanam yang berbeda. J. Hort. Indonesia. 5(1):47-55.

Grosch, D.S., L.E. Hapwood. 1979. Biological Affects of Radiations. Ed ke-2. Academic Pr. New York (US).

Insani, R.C. 2013. Kesesuaian arah baris penerimaan radiasi surya dan kerapatan populasi terhadap pertumbuhan tanaman jagung. Skripsi. Institut Pertanian Bogor. Bogor.

Heldt, H.W. 1997. Plant Biochemistry and Molecular Biology. Oxford Univ Pr. New York.

[Kementan] Kementerian Pertanian. 2013. Peraturan Menteri Pertanian Republik 
Indonesia Nomor 12 Tahun 2013 tentang Pedoman Pelaksanaan Kredit Ketahanan Pangan dan Energi. Kementan. Jakarta.

Kautsar, A. 2012. Diferensiasi asal geografis kunyit (Curcuma domestica Val.) menggunakan fotometer portable dan analisis kemometrik. unpak.ac.id/ ejournal/download.php?file=mahasiswa \&id=463\&name=022167006.pdf. Bogor. [30 Januari 2013].

Ling, A.P.K, J.Y. Chia, S. Hussein, A.R. Harun. 2008. Physiological responses of Citrus sinensis to gamma irradiation. World Applied Sci J. 5(1): 12-19.

Markham, K.R. 1988. Cara Mengidentifikasi Flavonoid. Institut Teknologi Bandung. Bandung.

Odeigah, P.G.C, A.O.O Sanyinpeju, G.O Myers. 1998. Induced mutation in cowpea, Vigna unguiculata. Rev biol trop. http://www.ots.ac.cr./tropiweb/read/ revistas/46-3/odeigah. [21Februari 2013].

Pramono, S. 2011. Studi iradiasi sinar gamma pada tanaman iles-iles (Amorphophallus muelleri Blume). Skripsi. Institut Pertanian Bogor. Bogor.

Pribadi, E.R. 2012 Ags. Ketersediaan bahan baku tanaman obat hipertensi dan hiperglikemia dalam mendukung program saintifikasi jamu. Warta Penelitian dan Pengembangan Tanaman Industri. 18(2): 21.

Rahardjo, M., O. Rostiana. 2005. Budidaya Tanaman Kunyit. Balai Penelitian Tanaman Obat dan Aromatika. Bogor.

Rashid, K., A.B.M. Daran, A. Nezhadahmadi, K. Hazmi, S. Azhar, S. Efzueni. 2013. The effect of using gamma rays on morphological characteristics of ginger (Zingiber officinale) plants. Life Sci J. 10(1): 1538-1544.

Royani, J.I. 2012. Pengaruh iradiasi sinar gamma 60Co terhadap perubahan karakter morfologi, molekular, senyawa aktif tanaman sambiloto (Andrographis paniculata). Skripsi. Institut Pertanian Bogor. Bogor.

Satriani. 2010. Industri kunyit dan pemasarannya. http://blogs.unpad.ac.id/satriani/ 2010/05/31/industri-kunyit-danpemasarannya/. [24 April 2014].

Srivastava, N.K., S. Sharma, A. Misra. 2006. Influence of $\mathrm{Zn}$ on allocation of leafassimilated ${ }^{14} \mathrm{CO}_{2}$ into primary metabolites in relation to production of essential oil and curcumin in turmeric (Curcuma longa L). World Journal of Agri. Sci. 2(2): 201-207.

Syifa, N. 2012. Analisis kuantitatif kurkuminoid kunyit dengan metode HPLC dan spektrofotometri UV-VIS. Institut Pertanian Bogor. Bogor.

Van Harten, A.M. 1998. Mutation Breeding Theory and Practical Aplication. Cambridge University Pr. 353p. Cambridge.

Wardhani, M.U.D. 2005. Pengaruh iradiasi sinar gamma terhadap keragaan anggrek Brachypeza indusiata (Reichb. F) garay secara in vitro. Skripsi. Institut Pertanian Bogor. Bogor.

Wardiyati, T. 2009. Eksplorasi dan identifikasi tanaman temulawak (Curcuma xanthorrhiza Roxb.) dan kunyit (Curcuma domestica Val.) sebagai bahan baku industri biofarmaka : Identifikasi variasi genetik dan analisis kadar kurkumin. http://lppm.ub.ac.id/ wrp-con/uploads/2012/03/TatikWardiyati1.pdf. [15 Desember 2012].

Winarti, C., N. Nurdjanah. 2005. Peluang tanaman rempah dan obat sebagai sumber pangan fungsional. Jurnal Litbang Pertanian. 24(2); http://www. pustaka-deptan.go.id. Bogor. [21 Februari 2013].

Wulan, M.T. 2007. Peningkatan keragaman kembang sepatu (Hibiscus rosa-sinensis Linn.) melalui mutasi induksi dengan iradiasi sinar gamma. Skripsi. Institut Pertanian Bogor. Bogor. 